\title{
Performance Comparisons of Law Offices and Optimum Allocation of Debt Files Using Z-Fuzzy AHP
}

\author{
Cengiz Kahraman ${ }^{\mathrm{a}}$, Basar Oztaysi ${ }^{\mathrm{a}}$, Sezi Cevik Onar ${ }^{\mathrm{a}}$ \\ ${ }^{a}$ Industrial Engineering Department, Istanbul Technical University, Besiktas, Istanbul, 34367, Turkey \\ kahramanc@itu.edu.tr, oztaysib@itu.edu.tr, sezi@outlook.com
}

\begin{abstract}
The performance of law offices can be comparatively measured by multicriteria decision making methods. Linguistic assessments can be used in this process rather than exact numerical evaluations. The performance evaluation is generally realized in a vague and imprecise environment. Fuzzy set theory is often very beneficial for evaluating the subjective judgments of decision makers. The Analytic Hierarchy Process is the most used multi-criteria decision making method in the world because of its simplicity and efficiency. A Z-fuzzy number is a relatively new concept in fuzzy set theory that enables one to circumvent the limitations of ordinary fuzzy numbers. They give a better representation than ordinary fuzzy numbers. We use a Zfuzzy AHP to compare the performances of law offices and allocate the debt files according to their performances.
\end{abstract}

Keywords: Law offices, fuzzy MCDM, Zfuzzy number, AHP, Allocation

\section{Introduction}

Law firms come in a variety of shapes and sizes, ranging from single-attorney law practices to multistate, multi-staffed legal organizations. When a company needs legal service outsourcing, it can apply to these law firms. This legal service outsourcing is generally on the collection of their debts. The law firms' performance should be measured by the company. The debt files are allocated based on the past performances of the law offices. Performance measurement can be handled as a multicriteria decision making problem.

Within the framework of ordinary fuzzy sets, Zadeh [19] proposed the Z-fuzzy number which is an ordered pair of fuzzy numbers (A, B). The first component $\mathrm{A}$ represents the fuzzy restriction while the second component $\mathrm{B}$ is the reliability of the first component. Researchers claim Z-numbers perform better when describing human judgments and dealing with uncertainty than traditional fuzzy numbers since they can handle restraint and reliability functions [9]. In this paper, we convert the linguistic assessments to Z-fuzzy numbers and evaluate the law offices performances based on the Z-fuzzy AHP.

Analytic Hierarchy Process (AHP) is one of the most popular multi-criteria decision making method to assess, prioritize, rank, and evaluate decision choices that was originally developed by Thomas L. Saaty. In

AHP method, factors related to a decision making problem are categorized and consequently form a hierarchy. AHP uses the judgments of decision makers to form the decomposition of problems into hierarchies. Number of levels in the hierarchy represents problem complexity.

The rest of this paper is organized as follows. Section 2 summarizes the types of law offices and performance criteria. Section 3 summarizes Z-fuzzy numbers. Section 4 includes Z-Fuzzy number AHP method (Z-AHP). Section 5 applies Z-AHP method to performance measurement and allocation problem for law offices. Finally, the study is concluded in the last section.

\section{Law Offices and Performance Criteria}

Law firms come in a variety of shapes and sizes, ranging from single-attorney law practices to multistate, multi-staffed legal organizations. When a company needs legal service outsourcing, it can apply to these law firms.

There are a variety of law firms to choose from, generally broken down by size, type of practice, (for example, litigation, criminal defense, or transactional), location, or legal topic (like personal injury law, family law or tax law). While there is no one-size-fits all solution to solving legal problems, choosing the right law firm can make the difference between a successful outcome and missed opportunity. Knowing which law firm to hire will depend on a number of factors including your finances, geographical location, personal work preferences, and your specific legal challenge or need. Below is a summary of the various types of law firms available in most areas. Solo Law Firms: Solo law firms are run by a single lawyer. These "solo practitioners" typically handle general legal matters on a variety of topics ranging from personal injury law to family law, but may also specialize in one particular 
area of law, like patent law. Small Law Firms: Small law firms generally employ from two to ten attorneys. They often allow the lawyers an opportunity to collaborate with other lawyers on complicated or related legal matters such as debt collection. Large Law Firms: Large law firms can range in size from several dozens of lawyers and employees, to several thousands of employees and can exist in multiple cities, states, and even countries. Large law firms specialize in all areas of the law and typically have big legal departments, such as corporate, employment, and real estate groups. Litigation vs. Transactional Law Firms: Law firms are sometimes broken down by the type of legal services they offer. For example, a law firm might only focus on litigation, representing clients in court cases or it can focus on transactional matters involving heavy paperwork relating to disputes over money, property, and insurance. Criminal Law Firms: Law firms specializing in criminal defense against crimes such as securities fraud, driving under the influence and other crimes often focus on representing private clients who can afford their own criminal defense attorney.

In our study we deal with a telecommunication company having debt collection problems. The company outsource debt collection process to small law firms around the country. The performance of these law firms can be measured by the following criteria: debt collection success in the assigned files $(\$)$, early debt collection success (\%), difficulty coefficient of the assigned files, and conformance to their goals.

\section{Fuzzy AHP Approaches}

Fuzzy extensions of AHP have been obtained by using fuzzy numbers. Recently, ordinary fuzzy numbers have been extended to several different types of fuzzy numbers such as intuitionistic fuzzy numbers, Pythagorean fuzzy numbers and type-2 fuzzy numbers. These extensions have allowed new fuzzy AHP extensions to be developed in the literature that are briefly summarized as follows.

Ordinary fuzzy AHP methods have been proposed by various authors. The first one was introduced by Van Laarhoven and Pedrycz [17]. Buckley [5] used trapezoidal fuzzy numbers and derived fuzzy weights and fuzzy performance scores by using a geometric mean method. Boender et al. [6] modified Van Laarhoven and Pedrycz's [17] method and proposed a more robust approach. Chang [7] proposed an extent analysis method for deriving priorities from comparison matrices. Cheng [8] proposed a fuzzy AHP method based on both probability and possibility measures. Mikhailov [13] proposed a fuzzy extension of AHP which obtains crisp priorities based on an $\alpha$ cut of fuzzy numbers.

Kahraman et al. [12] developed an interval type-2 (IT2) fuzzy AHP method together with a new ranking method for type-2 fuzzy sets, and then applied the method to supplier selection. Sadiq and Tesfamariam [15] applied the concept of IFS to AHP which is called IF-AHP to handle both vagueness and ambiguity related uncertainties in the environmental decision making process. Abdullah et al. [2] applied IFS to the AHP method called IF-AHP to quantify vagueness uncertainties in AHP using IFS for the decisionmaking problem. Tuysuz and Simsek [16] developed a hesitant fuzzy linguistic term sets based AHP approach and applied it to the performance comparison of cargo firms. Kahraman et al. [11] developed a hesitant fuzzy linguistic AHP and applied it to Business-to-Customer marketplace prioritization. Oztaysi et al. [14] developed a hesitant fuzzy AHP method involving multi-expert's linguistic evaluations aggregated by ordered weighted averaging (OWA) operator.

Ilbahar et al. [10] developed a novel approach to risk assessment for occupational health and safety using Pythagorean fuzzy AHP and fuzzy inference system. Abdel-Basset et al. [1] integrated AHP into a Delphi framework under a neutrosophic environment and introduced a new technique for checking consistency and calculating the consensus degree of an expert's opinions.

\section{Z-Fuzzy Numbers}

Zadeh [18] defined a Z-number associated with an uncertain variable $Z$ as an ordered pair of fuzzy numbers, (A, B) where A is a fuzzy subset of the domain $\mathrm{X}$ of the variable $\mathrm{Z}$ and $\mathrm{B}$ is a fuzzy subset of the unit interval. The concept of a Z-number is intended to provide a basis for computation with numbers which are not totally reliable. A Z-number can be used to represent information about an uncertain variable of the type where A represents a value of the variable and $B$ represents an idea of certainty or probability. There are a limited number of studies on Z-fuzzy numbers. Biswas [4] observed the drawback of the existing fuzzy numbers, studied Zfuzzy numbers and presented fundamental arithmetic operations for Z-fuzzy numbers. Abu Bakar and Gegov [3] conducted a study ranking Z-numbers by proposing a multi-layer decision making methodology. Biswas [4] discussed whether or not the fuzzy set theory was appropriate for large size problems with a number of universes and a lot of elements in these universes. In the study, the researcher also focused on Z-fuzzy numbers and their mathematical operations.

Definition 1. A Z-number is an ordered pair of fuzzy numbers denoted as $Z=(\widetilde{A}, \widetilde{R})$. The first component $\widetilde{\mathrm{A}}$, a restriction on the values, is a real-valued uncertain variable $X$. The second component $\widetilde{R}$ is a measure of reliability for the first component, described in Figure 2. When $a_{2}$ equals $a_{3}$, a trapezoidal fuzzy number becomes a triangular fuzzy number. 
Definition 2. Let a fuzzy set $A$ be defined on a universe $X$ be given as: $\mathrm{A}=\left\{\left\langle\mathrm{x}, \mu_{\mathrm{A}}(\mathrm{x})\right\rangle \mid \mathrm{x} \in \mathrm{X}\right\}$ where $\mu_{A}: X \rightarrow[0,1]$ is the membership function $A$. The membership value $\mu_{A}(x)$ describes the degree of belonging of $\mathrm{x} \in \mathrm{X}$ in $A$. The Fuzzy Expectation of a fuzzy set is denoted as:

$E_{A}(x)=\int_{x} x \mu_{A}(x) d x$

which is not the same as the meaning of the Expectation of Probability Space. It can be considered to be the Information Strength supporting the fuzzy set A.

\section{Definition 3: Converting a Z-number to a regular} fuzzy number (Kang et al. [20])

Consider a Z-number $Z=(\widetilde{A}, \widetilde{R})$ described by Figure 2 . The left is the part of restriction, and the right is the part of reliability. Let $\tilde{A}=$ $\left\{\left\langle x, \mu_{\tilde{A}}(x)\right\rangle \mid \mu(x) \in[0,1]\right\} \quad$ and $\quad \tilde{R}=$ $\left\{\left\langle x, \mu_{\tilde{R}}(x)\right\rangle \mid \mu(x) \in[0,1]\right\}, \mu_{\tilde{A}}(x)$ is a trapezoidal membership function, and $\mu_{\tilde{R}}(x)$ is a triangular membership function.

1. Convert the second part (reliability) into a crisp number using Equation 2.

$\alpha=\frac{\int x \mu_{\widetilde{R}}(x) d x}{\int \mu_{\widetilde{R}}(x) d x}$

where $\int$ denotes an algebraic integration.

Alternatively, Equation 3 can be used for this defuzzification:

$\alpha=\frac{a_{1}+2\left(a_{2}+a_{3}\right)+a_{4}}{6}$

2. Add the weight of the second part (reliability) to the first part (restriction). The weighted Z-number can be denoted as $\tilde{Z}^{\alpha}=\left\{\left(x, \mu_{\tilde{A}^{\alpha}}(x)\right) \mid \mu_{\tilde{A}^{\alpha}}(x)\right\}=\alpha \mu_{\tilde{A}}(x), \mu(x) \epsilon[0,1]$.

3. Convert the irregular fuzzy number (weighted restriction) to a regular fuzzy number. The

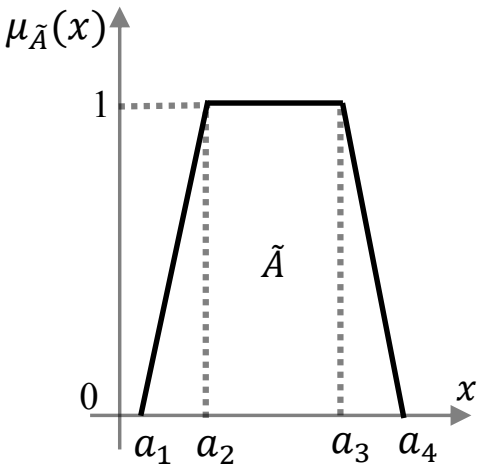

ordinary fuzzy set can be denoted as $\tilde{\mathrm{Z}}^{\prime}=$ $\left\{\left\langle\mathrm{x}, \mu_{\widetilde{\mathrm{Z}}^{\prime}}(\mathrm{x})\right\rangle \mid \mu_{\widetilde{\mathrm{Z}}^{\prime}}(\mathrm{x})=\mu_{\widetilde{\mathrm{A}}}\left(\frac{\mathrm{x}}{\sqrt{\alpha}}\right), \mu(\mathrm{x}) \in[0,1]\right\} . \tilde{Z}^{\prime}$ has the same Fuzzy Expectation with $\tilde{Z}^{\alpha}$, and they are equal with respect to Fuzzy Expectation, which can be denoted by Figure 3.

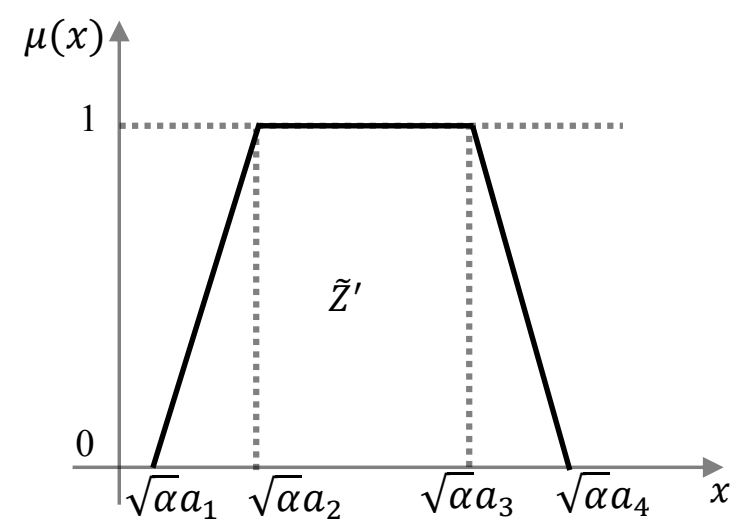

Figure 3 Ordinary fuzzy number transformed from Zfuzzy number

\section{Z- fuzzy number based AHP}

In this method we integrate z-fuzzy numbers with AHP. The advantage of this integration is to incorporate vagueness in the evaluations and reliabilities to these evaluations into the AHP. The steps of the proposed Z-fuzzy number based-AHP are presented in the following:

Step 1. Define the multi-criteria decision making problem and design a hierarchical structure of the problem.

Step 2. Use the scale of linguistic restriction function given in Table 1 and the scale of reliability function presented in Table 2. These are the original scales that have been proposed by us.

Figure 2 A simple $Z$-fuzzy number, $Z=(\tilde{A}, \tilde{R})$ 
Table 1. Triangular restriction scale

\begin{tabular}{|l|c|}
\hline Linguistic Terms & $\begin{array}{c}\text { Restriction } \\
\text { function }\end{array}$ \\
\hline Equal (E) & $(1,1,1 ; 1)$ \\
\hline Slightly Better (SLB) & $(1,1,3 ; 1)$ \\
\hline Moderately Better (MB) & $(1,3,5 ; 1)$ \\
\hline Strongly Better (STB) & $(3,5,7 ; 1)$ \\
\hline $\begin{array}{l}\text { Very Strongly Better } \\
\text { (VSTB) }\end{array}$ & $(5,7,9 ; 1)$ \\
\hline Certainly Better (CB) & $(7,9,10 ; 1)$ \\
\hline Absolutely Better (AB) & $(9,10,10 ; 1)$ \\
\hline
\end{tabular}

Table 2. Reliability scale

\begin{tabular}{|l|c|}
\hline Linguistic Reliability & $\begin{array}{c}\text { Triangular } \\
\text { reliability function }\end{array}$ \\
\hline Absolutely Reliable (AR) & $(0.8,0.9,1 ; 1)$ \\
\hline Strongly Reliable (SR) & $(0.7,0.8,0.9 ; 1)$ \\
\hline $\begin{array}{l}\text { Very Highly Reliable } \\
\text { (VHR) }\end{array}$ & $(0.6,0.7,0.8 ; 1)$ \\
\hline Highly Reliable (HR) & $(0.5,0.6,0.7 ; 1)$ \\
\hline Fairly Reliable (FR) & $(0.4,0.5,0.6 ; 1)$ \\
\hline Weakly Reliable (WR) & $(0.3,0.4,0.5 ; 1)$ \\
\hline $\begin{array}{l}\text { Very Weakly Reliable } \\
\text { (VWR) }\end{array}$ & $(0.2,0.3,0.4 ; 1)$ \\
\hline Strongly Unreliable (SU) & $(0.1,0.2,0.3 ; 1)$ \\
\hline Absolutely Unreliable (AU) & $(0,0.1,0.2 ; 1)$ \\
\hline
\end{tabular}

Decision makers may assign different values for the given linguistic terms and correspondingly different fuzzy restriction functions in Table 1 if s/he wants to assign intermediate values.

Step 3. Construct the pairwise comparison matrices and fill them in with their corresponding Z-fuzzy numbers using the linguistic scales in Tables 1 and 2 . Step 4. Transform Z-fuzzy numbers to their corresponding equivalent ordinary fuzzy numbers.

Step 5. Check the consistency of each fuzzy pairwise comparison matrix. Assume $\tilde{A}=\left\lfloor\tilde{a}_{i j}\right\rfloor$ is a fuzzy positive pairwise comparison matrix and $A=\left\lfloor a_{i j}\right\rfloor$ is its defuzzified positive pairwise comparison matrix. If the result of the comparisons of $A=\left[a_{i j}\right\rfloor$ is consistent; then, it can imply that the result of the comparisons of $\tilde{A}=\left[\tilde{a}_{i j}\right]$ is also consistent. In the consistency measurement, reliability functions are ignored since they cause a consistent pairwise comparison matrix to become an inconsistent one when they are converted to regular fuzzy numbers.

Step 6. Apply Buckley's ordinary fuzzy AHP method [5]. The steps of this method are summarized as follows:

Step 6.1. Calculate the geometric mean for each parameter of $\tilde{a}_{i j}$ in the $\mathrm{n}$ dimensional pairwise comparison matrix of criteria. Thus, $n \times n$ matrix is converted to an $n \times 1$ matrix. This is the step that converts Z-fuzzy numbers to regular fuzzy numbers.

Step 6.2. Sum the values of each parameter in the column then normalize the values in the $n \times 1$ matrix. Step 6.3. Apply the fuzzy division operation to get the normalized weights vector.

Step 6.4. Defuzzify the normalized weights vector using the center of gravity method given by Eq. (2).

Step 6.5. Normalize the weights so their sum is equal to 1 .

Step 6.6. Apply Steps (6.1-6.5) for the rest of the pairwise comparison matrices of sub-criteria and alternatives.

Step 6.7. Combine all the weight vectors to obtain the global weights and determine the best alternative as in the classical AHP.

\section{An Application}

The problem involves five criteria and four law office alternatives. There are three experts E1, E2, and E3 whose weights are $0.3,0.2$, and 0.5 , respectively. The pairwise comparison matrices for the criteria and alternatives are presented in Table 2 and Table 3 . The performance of law offices is measured by the following criteria. $\mathrm{C} 1$ : loan collection success in the assigned files (\$), C2: early loan collection success (\%), C3: difficulty coefficient of the assigned files, $\mathrm{C} 4$ : customer complaints, and C5: conformance to their goals.

Table 2. Z-Fuzzy comparisons for the criteria

\begin{tabular}{|c|c|c|c|c|c|c|c|c|c|c|c|}
\hline DM1 & $\mathrm{C} 1$ & $\mathrm{C} 2$ & C3 & $\mathrm{C} 4$ & C5 & DM2 & $\mathrm{C} 1$ & $\mathrm{C} 2$ & C3 & $\mathrm{C} 4$ & $\mathrm{C5}$ \\
\hline $\mathrm{C} 1$ & $\mathrm{E}, \mathrm{E}$ & $\begin{array}{l}\text { 1/AB, } \\
\text { SR }\end{array}$ & $\begin{array}{c}1 / \mathrm{CB}, \\
\mathrm{AR}\end{array}$ & $\begin{array}{c}\text { 1/MB, } \\
\text { SR }\end{array}$ & $\begin{array}{c}1 / \mathrm{STB}, \\
\text { FR }\end{array}$ & $\mathrm{C} 1$ & $\mathrm{E}, \mathrm{E}$ & $\begin{array}{c}\text { 1/SLB, } \\
\text { VHR }\end{array}$ & $\begin{array}{c}\text { STB, } \\
\text { SR }\end{array}$ & SLB, SR & $\begin{array}{l}\text { CB, } \\
\text { SR }\end{array}$ \\
\hline $\mathrm{C} 2$ & $\begin{array}{c}\mathrm{AB}, \\
\mathrm{SR}\end{array}$ & $\mathrm{E}, \mathrm{E}$ & $\begin{array}{c}\text { 1/SLB, } \\
\text { VHR }\end{array}$ & $\begin{array}{c}\text { STB, } \\
\text { SR }\end{array}$ & $\begin{array}{c}\text { SLB, } \\
\text { SR }\end{array}$ & $\mathrm{C} 2$ & $\begin{array}{l}\text { SLB, } \\
\text { VHR }\end{array}$ & $\mathrm{E}, \mathrm{E}$ & $\begin{array}{l}\text { VSTB, } \\
\text { SR }\end{array}$ & $\begin{array}{l}\text { MB, } \\
\text { VHR }\end{array}$ & $\begin{array}{l}\mathrm{AB}, \\
\mathrm{AR}\end{array}$ \\
\hline C3 & $\begin{array}{l}\mathrm{CB}, \\
\mathrm{AR}\end{array}$ & $\begin{array}{l}\text { SLB, } \\
\text { VHR }\end{array}$ & $\mathrm{E}, \mathrm{E}$ & $\begin{array}{c}\text { VSTB, } \\
\text { SR }\end{array}$ & $\begin{array}{l}\text { MB, } \\
\text { VHR }\end{array}$ & C3 & $\begin{array}{c}1 / \mathrm{STB}, \\
\text { SR }\end{array}$ & $\begin{array}{c}\text { 1/VSTB, } \\
\text { SR }\end{array}$ & $\mathrm{E}, \mathrm{E}$ & $\begin{array}{c}\text { 1/MB, } \\
\text { SR }\end{array}$ & $\begin{array}{l}\text { STB, } \\
\text { VHR }\end{array}$ \\
\hline $\mathrm{C} 4$ & $\begin{array}{l}\text { MB, } \\
\text { SR }\end{array}$ & $\begin{array}{c}\text { 1/STB, } \\
\text { SR }\end{array}$ & $\begin{array}{l}\text { 1/VSTB, } \\
\text { SR }\end{array}$ & $\mathrm{E}, \mathrm{E}$ & $\begin{array}{c}\text { 1/MB, } \\
\text { SR }\end{array}$ & $\mathrm{C} 4$ & $\begin{array}{c}\text { 1/SLB, } \\
\text { SR }\end{array}$ & $\begin{array}{l}\text { 1/MB, } \\
\text { VHR }\end{array}$ & $\begin{array}{c}\text { MB, } \\
\text { SR }\end{array}$ & $\mathrm{E}, \mathrm{E}$ & $\begin{array}{c}\text { VSTB, } \\
\text { AR }\end{array}$ \\
\hline $\mathrm{C5}$ & $\begin{array}{l}\text { STB, } \\
\text { FR }\end{array}$ & $\begin{array}{c}1 / \mathrm{SLB}, \\
\mathrm{SR}\end{array}$ & $\begin{array}{l}\text { 1/MB, } \\
\text { VHR }\end{array}$ & $\begin{array}{c}\mathrm{MB}, \\
\text { SR }\end{array}$ & $\mathrm{E}, \mathrm{E}$ & $\mathrm{C} 5$ & $\begin{array}{c}1 / \mathrm{CB}, \\
\mathrm{SR}\end{array}$ & $\begin{array}{c}1 / \mathrm{AB}, \\
\mathrm{AR}\end{array}$ & $\begin{array}{c}\text { 1/STB, } \\
\text { VHR }\end{array}$ & $\begin{array}{c}\text { 1/VSTB, } \\
\text { AR }\end{array}$ & $\mathrm{E}, \mathrm{E}$ \\
\hline
\end{tabular}

Table 2. Z-Fuzzy comparisons for the criteria (continues) 


\begin{tabular}{|l|l|l|l|l|l|}
\hline $\mathrm{DM} 3$ & $\mathrm{C} 1$ & $\mathrm{C} 2$ & $\mathrm{C} 3$ & $\mathrm{C} 4$ & $\mathrm{C} 5$ \\
\hline $\mathrm{C} 1$ & $\mathrm{E}, \mathrm{E}$ & $\mathrm{SLB}, \mathrm{VHR}$ & $1 / \mathrm{CB}, \mathrm{HR}$ & $1 / \mathrm{VSTB}, \mathrm{FR}$ & $1 / \mathrm{MB}, \mathrm{SR}$ \\
\hline $\mathrm{C} 2$ & $1 / \mathrm{SLB}, \mathrm{VHR}$ & $\mathrm{E}, \mathrm{E}$ & $1 / \mathrm{AB}, \mathrm{SR}$ & $1 / \mathrm{CB}, \mathrm{AR}$ & $1 / \mathrm{MB}, \mathrm{SR}$ \\
\hline $\mathrm{C} 3$ & $\mathrm{CB}, \mathrm{HR}$ & $\mathrm{AB}, \mathrm{SR}$ & $\mathrm{E}, \mathrm{E}$ & $1 / \mathrm{SLB}, \mathrm{VHR}$ & $\mathrm{STB}, \mathrm{SR}$ \\
\hline $\mathrm{C} 4$ & $\mathrm{VSTB}, \mathrm{FR}$ & $\mathrm{CB}, \mathrm{AR}$ & $\mathrm{SLB}, \mathrm{VHR}$ & $\mathrm{E}, \mathrm{E}$ & $\mathrm{VSTB}, \mathrm{SR}$ \\
\hline $\mathrm{C} 5$ & $\mathrm{MB}, \mathrm{SR}$ & $\mathrm{MB}, \mathrm{SR}$ & $1 / \mathrm{STB}, \mathrm{SR}$ & $1 / \mathrm{VSTB}, \mathrm{SR}$ & $\mathrm{E}, \mathrm{E}$ \\
\hline
\end{tabular}

Table 3. Z-Fuzzy comparisons for the alternatives

\begin{tabular}{|c|c|c|c|c|c|c|c|c|c|}
\hline DM1 & A1 & A2 & A3 & A4 & DM2 & A1 & A2 & A3 & A4 \\
\hline $\mathrm{A} 1$ & $\mathrm{E}, \mathrm{E}$ & $\begin{array}{l}\text { 1/AB, } \\
\text { VHRR }\end{array}$ & $\begin{array}{c}1 / \mathrm{CB}, \\
\mathrm{SR}\end{array}$ & $\begin{array}{c}1 / \mathrm{STB}, \\
\mathrm{SR}\end{array}$ & A1 & $\mathrm{E}, \mathrm{E}$ & $\begin{array}{c}\text { 1/SLB, } \\
\text { SR }\end{array}$ & STB, SR & $\begin{array}{l}\text { SLB, } \\
\text { VHR }\end{array}$ \\
\hline $\mathrm{A} 2$ & $\begin{array}{c}\text { AB, } \\
\text { VHR }\end{array}$ & $\mathrm{E}, \mathrm{E}$ & $\begin{array}{l}\text { 1/SLB, } \\
\text { VHR }\end{array}$ & $\begin{array}{c}\text { STB, } \\
\text { SR }\end{array}$ & $\mathrm{A} 2$ & $\begin{array}{l}\text { SLB, } \\
\text { SR }\end{array}$ & $\mathrm{E}, \mathrm{E}$ & $\begin{array}{c}\text { 1/VSTB, } \\
\text { VHR }\end{array}$ & $\begin{array}{l}\text { MB, } \\
\text { VHR }\end{array}$ \\
\hline A3 & $\begin{array}{c}\mathrm{AB}, \\
\mathrm{SR}\end{array}$ & $\begin{array}{l}\text { SLB, } \\
\text { VHR }\end{array}$ & E, E & $\begin{array}{l}\mathrm{AB}, \\
\mathrm{HR}\end{array}$ & $\mathrm{A} 3$ & $\begin{array}{l}\mathrm{AB}, \\
\mathrm{SR}\end{array}$ & $\begin{array}{l}\text { VSTB, } \\
\text { VHR }\end{array}$ & E, E & $\begin{array}{c}\mathrm{AB}, \\
\mathrm{SR}\end{array}$ \\
\hline $\mathrm{A} 4$ & $\begin{array}{c}\text { STB, } \\
\text { SR, }\end{array}$ & $\begin{array}{c}1 / \mathrm{STB}, \\
\text { SR }\end{array}$ & $\begin{array}{c}\text { 1/VSTB, } \\
\text { HR }\end{array}$ & E, E & A4 & $\begin{array}{c}\text { 1/SLB, } \\
\text { VHR }\end{array}$ & $\begin{array}{l}1 / \mathrm{MB}, \\
\text { VHR }\end{array}$ & $\mathrm{MB}, \mathrm{SR}$ & $\mathrm{E}, \mathrm{E}$ \\
\hline
\end{tabular}

\begin{tabular}{|l|l|l|l|l|}
\hline DM3 & A1 & A2 & A3 & A4 \\
\hline A1 & E, E & AB, SR & $1 / \mathrm{AB}, \mathrm{HR}$ & $1 / \mathrm{VSTB}, \mathrm{HR}$ \\
\hline $\mathrm{A} 2$ & $1 / \mathrm{AB}, \mathrm{SR}$ & $\mathrm{E}, \mathrm{E}$ & $1 / \mathrm{AB}, \mathrm{SR}$ & $1 / \mathrm{CB}, \mathrm{AR}$ \\
\hline $\mathrm{A} 3$ & $\mathrm{AB}, \mathrm{HR}$ & $\mathrm{AB}, \mathrm{SR}$ & $\mathrm{E}, \mathrm{E}$ & $\mathrm{VSB}, \mathrm{VHR}$ \\
\hline $\mathrm{A} 4$ & $\mathrm{VSTB}, \mathrm{HR}$ & $\mathrm{CB}, \mathrm{AR}$ & $1 / \mathrm{VSB}, \mathrm{VHR}$ & $\mathrm{E}, \mathrm{E}$ \\
\hline
\end{tabular}

Table 4. Aggregated triangular fuzzy numbers converted from Table 2

\begin{tabular}{|l|l|l|l|l|l|}
\hline & \multicolumn{1}{|c}{ C1 } & \multicolumn{1}{|c|}{ C2 } & \multicolumn{1}{c|}{ C3 } & \multicolumn{1}{c|}{ C4 } & \multicolumn{1}{c|}{ C5 } \\
\hline C1 & $(1,1,1 ; 1)$ & $(0.84,0.84,2.51 ; 1)$ & $(0.08,0.09,0.11 ; 1)$ & $(0.08,0.10,0.14 ; 1)$ & $(0.18,0.30,0.89 ; 1)$ \\
\hline C2 & $(0.28,0.84,0.84 ; 1)$ & $(1,1,1 ; 1)$ & $(0.09,0.09,0.10 ; 1)$ & $(0.09,0.11,0.14 ; 1)$ & $(0.18,0.30,0.89 ; 1)$ \\
\hline C3 & $(5.42,6.97,7.75 ; 1)$ & $(8.05,8.94,8.94 ; 1)$ & $(1,1,1 ; 1)$ & $(0.28,0.84,0.84 ; 1)$ & $(2.68,4.47,6.26 ; 1)$ \\
\hline C4 & $(3.54,4.95,6.36 ; 1)$ & $(6.64,8.54,9.49 ; 1)$ & $(0.84,0.84,2.51 ; 1)$ & $(1,1,1 ; 1)$ & $(4.47,6.26,8.05 ; 1)$ \\
\hline C5 & $(1.12,2.68,4.47 ; 1)$ & $(0.89,2.68,4.47 ; 1)$ & $(0.13,0.18,0.30 ; 1)$ & $(0.10,0.13,0.18 ; 1)$ & $(1,1,1 ; 1)$ \\
\hline
\end{tabular}

Similarly, aggregated TFNs converted from Table 3 are obtained. Because of the space constraints, we do not give the rest of the calculations. The final ranking between the law office alternatives is $\mathrm{A} 3>\mathrm{A} 1>\mathrm{A} 4>\mathrm{A} 2$.

\section{Conclusion}

The performance measurement of law offices is a complex task because of several conflicting and linguistic criteria. Fuzzy set approaches are excellent tools to handle such problems under uncertainty. Z-fuzzy set approaches involve both the restriction and reliability functions in the decision process. This provides more realistic and correct results at the end of the decision making process. The proposed Z-fuzzy number based AHP method evaluated the law offices successfully.

As for future work, fuzzy inference systems can be used for debt collection problem [21]. Besides, other fuzzy MADM methods like intuitionistic fuzzy AHP [22], hesitant fuzzy AHP [23], intuitionistic fuzzy ANP [24], spherical fuzzy VIKOR [25], spherical fuzzy WASPAS [26], single-valued spherical TOPSIS [27] or intervalvalued spherical fuzzy TOPSIS [28] can be used in evaluating law offices and can be compared with the findings of the current study.

\section{References}

[1] Abdel-Basset, M., Mohamed. M., \& Sangaiah A.K. (2017). Neutrosophic AHP-Delphi group decision making model based on trapezoidal neutrosophic numbers. Journal of Ambient Intelligence and Humanized Computing, 1-17.

[2] Abdullah, L., Jaafar. S., \& Taib. I. (2009). A new Analytic Hierarchy Process in multiattribute group decision making. International Journal of Soft Computing, 4(5), 208-214.

[3] Abu Bakar, A.S., Gegov, A. (2015). Multilayer decision methodology for ranking Znumbers. International Journal of 
Computational Intelligence Systems, 8(2), 395406.

[4] Biswas, R. (2012). Fuzzy numbers redefined. Information, 15(4), 1369-1380.

[5] Buckley, J.J. (1985). Fuzzy hierarchical analysis. Fuzzy Sets and Systems, 17(3), 233247.

[6] Boender, C.G.E., De Graan. J.G., \& Lootsma. F.A. (1989). Multicriteria decision analysis with fuzzy pairwise comparisons. Fuzzy Sets and Systems, 29(2), 133-143.

[7] Chang, D.Y. (1996). Applications of the extent analysis method on fuzzy AHP. European Journal of Operational Research, 95(3), 649655.

[8] Cheng, C.H. (1997). Evaluating naval tactical missile systems by fuzzy AHP based on the grade value of membership function. European Journal of Operational Research, 96(2), 343350.

[9] Deng, Y., Chan, F. T. S. (2011). A new fuzzy dempster MCDM method and its application in supplier selection. Expert Systems with Applications, 38, 9854-986.

[10] Ilbahar, E., Karaşan, A., Cebi, S., \& Kahraman, C. (2018). A novel approach to risk assessment for occupational health and safety using Pythagorean fuzzy AHP \& fuzzy inference system. Safety Science, 103, 124136.

[11] Kahraman, C., Çevik Onar, S., \& Öztayşi, B. (2017). B2C Marketplace prioritization using hesitant fuzzy linguistic AHP. International Journal of Fuzzy Systems, 20(7), 2202-2215.

[12] Kahraman, C., Öztayşi, B., Sarı, İ.U. \& Turanoğlu, E. (2014). Fuzzy Analytic Hierarchy Process with interval type-2 fuzzy sets. Knowledge-Based Systems, 59, 48-57.

[13] Mikhailov, L. (2003). Deriving priorities from fuzzy pairwise comparison judgements. Fuzzy Sets and Systems, 134(3), 365-385.

[14] Oztaysi, B., Cevik Onar, S., Bolturk, E.. \& Kahraman, C. (2015). Hesitant fuzzy Analytic Hierarchy Process, IEEE International Conference on Fuzzy Systems, 1-7.

[15] Sadiq, R., \& Tesfamariam, S. (2009). Environmental decision-making under uncertainty using intuitionistic fuzzy Analytic Hierarchy Process (IF-AHP). Stochastic Environmental Research and Risk Assessment, 23(1), 75-91.

[16] Tuysuz, F. \& Şimşek, B. (2017). A hesitant fuzzy linguistic term sets-based AHP approach for analyzing the performance evaluation factors: an application to cargo sector. Complex \& Intelligent Systems, 3(3), 167-175.

[17] Van Laarhoven, P.J.M., \& Pedrycz, W. (1983). A fuzzy extension of Saaty's priority theory. Fuzzy Sets and Systems, 11(1), 199-227.
[18] Zadeh, L.A. (1975). The concept of a linguistic variable and its application to approximate reasoning. Information Sciences, 8(3), 199249.

[19] Zadeh, L.A. (2011). A note on Z-numbers. Information Sciences, 181, 2923-2932.

[20] Kang, B., Wei, D., Li, Y., Deng, Y. (2012) A method of converting $\mathrm{Z}$-number to classical fuzzy number, Journal of Information \& Computational Science 9(3), 703-709.

[21] Behret H., Oztaysi B., Kahraman C. (2011) A fuzzy inference system for supply chain risk management, Practical applications of intelligent systems, 429-438.

[22] Otay I., Oztaysi B., Cevik Onar S., Kahraman C. (2017) Multi-expert performance evaluation of healthcare institutions using an integrated intuitionistic fuzzy AHP\&DEA methodology, Knowledge-Based Systems 133, 90-106.

[23] Kahraman C., Oztaysi B., Cevik Onar S. (2014) A multicriteria supplier selection model using hesitant fuzzy linguistic term sets, Decision Making and Soft Computing: Proceedings of the 11th International FLINS Conference, 3641.

[24] A Karaşan, C Kahraman (2017) A novel intuitionistic fuzzy DEMATEL-ANPTOPSIS integrated methodology for freight village location selection, Journal of Intelligent \& Fuzzy Systems, 36(2), 1335-1352.

[25] F. Kutlu Gündoğdu \& C. Kahraman, A novel VIKOR method using spherical fuzzy sets and its application to warehouse site selection. Journal of Intelligent \& Fuzzy Systems (2019) Pre-press.

[26] F. Kutlu Gündoğdu \& C. Kahraman, Extension of WASPAS with spherical fuzzy sets. Informatica (2019) 30(2): 269-292.

[27] F. Kutlu Gündoğdu \& C. Kahraman, Spherical fuzzy sets and spherical fuzzy TOPSIS method. Journal of Intelligent \& Fuzzy Systems Preprint (2019) 36(1): 337-352.

[28] F. Kutlu Gündoğdu \& C. Kahraman, A novel fuzzy TOPSIS method using emerging interval-valued spherical fuzzy sets. Engineering Applications and Artificial Intelligence (2019) Pre-press. 